\title{
The Quest for Acceptance
}

\section{Alberto Balam Navarro}

Mrs. Migglets burst through the door and began yelling as if her life depended on it.

"Can someone explain to me why in God's name any of you would ever do this? I do not have a Bill Clinton, a Spongebob, or a Balam in my class! Whoever decided to pull this little stunt is going to suffer some serious consequences."

These words marked the end of my time being known as Balam, a name given to me by my father. It's Mayan and it means jaguar warrior, how awesome is that! Growing up in Mexico, I proudly told people that I was Balam the warrior jaguar that defended the once great cities of the Mayan empire. While many did not care to know what it meant, I said it with a conviction that would topple the strongest armies in the world. It was my name, at doctor's appointments, at school, and of course, in every family interaction. I knew that my parents had given me another name-Alberto- but who would want to be named that? I could see Albert being interesting since there have been some serious advancements by individuals named Albert, but Alberto, give me a break you might as well call me Carl or something else. But all of this changed when I decided that I would never be called Balam again by anyone who was not my family or friend, hell even my closest friends do not even know I have another name besides Alberto.

My life changed because I did the one thing I was asked to do in the best possible manner I could: write my name on the a get-to-know me activity that was given to me by my fourth grade teacher on my first day in the state of Texas. That was the defining moment in my life that made me re-evaluate the manner in which I would identify myself. I was born in National City, a city in San Diego County. My father was working for CASIO electronics at the time and wanted to make sure that if his position ever needed him to move to the United States he would not have an issue with my legal paperwork. But since my place of birth was only determined to avoid an immigration problem, for the first six years of my life I lived in Tijuana, Mexico. It was there where I would be educated in my first language, Spanish, as well as the culture and mannerisms that I thought would be the ones that I would follow my whole life. From what I remember, as a little boy, I lived in a colossal mansion --my height at the time was a large factor in this description of my one story, three bedroom, one bathroom house-- and I enjoyed life as the intrepid adventurer every child believes he is. At school, I was successful with all of my course work and I loved to draw and paint more than anything. It was customary to have the star student in the kindergarten group, read a poem during the morning 
announcements after the pledge of allegiance, which I did more than once. I can remember one instance in which I had to memorize a strange long poem and I could not fix the final lines in memory. When the moment of truth came I reached the final stanza without hesitation and stopped. I could not remember the final verse and simply said: "And uh...uh yeah, that is all I know," after which all eight hundred of the students in the school and every teacher on site began laughing. That's who I was in the foreign and unknown world many people in the United States call "Mexico."

When my father first told me that he no longer had his visa because the company shut down the factory he was employed at due to a restructuring, I asked myself what that meant for the rest of us. The answer was simple, moving away, far away to a distant land that spoke another language and had people that looked like the principal at my school but with blonde hair. I was terrified, in shock, and curious, all at the same time. I feared the idea of being stripped of all the things I had come to know as home and family but at the same time I wondered what life on the other side had to offer and if it would be worth it.

My parents told me that we would stay with an aunt of mine in Yuma, Arizona, a state I had only heard about in western movies. If you have never been, let me advise you with one word that will summarize the experience: don't. From dusk till dawn, triple degree temperatures heat the atmosphere and make life a living hell. My father went from being a managing supervisor at a major distribution plant to being a handyman who installed the electrical wiring in apartment complexes that we could not afford to live in. It would be here, in this wretched place that I would have my first introduction to my brave new world. I will never forget my first day at the foreign-sounding "elementary" school (rather than a "primary" school, as they say in Mexico). My mother walked me in and with the little English she knew was able to ask for directions to my classroom. Walking into a new academic setting, especially one that is in a different language was like an expedition into an alien world. The way the classroom was structured did not allow for the people inside to see who was entering the room and vice versa. The first person I was introduced to was Mrs. Foster, a sweet young woman who always seemed to be wearing a cardigan in spite of the Arizona heat. She asked me what my name was, I looked at my mother who translated what she had said, and I simply replied Balam. Mrs. Foster made a funny face and said well come in and meet everyone. The thing I was most curious about was the way those people looked. I was relieved that not everyone was white. I was introduced, I sat down, and no one really cared or acknowledged me. It seemed like I was just taking up some space in the classroom.

The first couple of weeks were hard. I would get into trouble for not paying attention or not completing assignments, but it was not because I wanted to be a bad kid, I just did not know what was going on. The criticism, confusion, and frustration made me flee. I ran from my teacher, found the school's Spanish speaking secretary, and begged her to get someone to pick me up. After that, they put me in an ESL program. After the third month, I no longer struggled to understand but continued to participate in ESL activities and was able to be left with the other kids for longer periods of time. While my English may not have been perfect, it was manageable and functional. Then I found out we were moving to California. My life would change again, but this time for the better.

Being anywhere near the water is always a plus, and California has some of the best beaches on earth next only to Australia. Since I knew how to speak English, at this point I was eager to get into the classroom 
and prove myself as the bright student I truly was. My first day included an earthquake drill and realizing that I no longer had the accent that separated me from the other children. It would be here in California that I would understand and appreciate my new living circumstances. I stopped feeling homesick because I no longer felt as if Mexico or any part of the culture was mine. My accent, which made understanding me difficult, softened to the point that people could understand me. I came to terms that I was no longer the kid that was displaced; my home was now the United States, this was my new reality. Since my English still wasn't at an acceptable level for the ESL instructors, I continued to be dragged out of class and asked to participate in drills and exercises to improve my English. As mentioned before, I constantly try to take advantage of the situation and make jokes whenever possible. I stayed in California for two years and completed my second and third-grade education with impeccable notes. At this point I was still Balam. No one ever called me Alberto, not even my parents. How did this come to change? Let me tell you.

"Mom I promise I didn't do anything wrong! I just wrote down my name and the teacher started yelling, she said I made up Balam!" My parents refused to believe that I had failed an assignment due to the manner in which I identified myself. My teacher, Mrs. Migglets, informed my parents that several students had decided to pull a practical joke where they replaced their real names with either celebrity names or made up nonsense. My father was appalled, but since I was the new kid he simply pulled out my birth certificate. Mrs. Migglets smirked and changed my grade. And that's how I became Alberto outside the house and Balam in it. Mrs. Migglets refused to acknowledge me as Balam and justified it by saying that no one goes by their middle name in the United States. My parents didn't understand why I was okay with this or why I would even entertain the idea of having two identities, but I guess it came with being bilingual. Alberto was the smart kid who made good grades and spoke English while Balam was the mischievous child who only showed up for half of the day and spoke developing Spanish. In retrospect, let's face it, these are things that I never really thought about at this age. SpongeBob was a lot more interesting in my life at that time, but the story of how I stopped being called Balam, and became Alberto, was a defining instance in my life.

The next couple of years were critical in that I stopped longing for the places and people I called family and home. This continued when we moved to Texas and I began to notice it in my relationship to Mexico. My mother and father would typically take their vacation days in the summer and drive us down to Mexico City where we would see our relatives. As a child, there was nothing that I wanted to do more than spend time with my father's family; I can't think of an instance in which I didn't beg for them to come visit us even if it was just for an hour. But that all changed. I started struggling to understand them and lost connection with the things they wanted to talk about. What once were heated conversations about Mexican soccer turned into awkward discussions about people I had never heard about and how they were getting close to winning a tournament I didn't care about. I missed my home, the United States, my friends, and my room. The reality was that I was no longer Mexican, I was American.

When I started high school I realized something very disturbing: the color of my skin created preconceived notions about just how smart I could be and where I would end up in life. Every time someone asked me where I was from I would say Grand Prairie, Texas, and they would then ask but I mean what are you? A human being I would respond. I mean are you Mexican or what? Why people would ask me this? I will 
never know. I did not see the point since I did not have an accent anymore. In high school, I also discovered that children that came up like me weren't all the same. The first individual that I met that told me they had parents from Mexico said that I spoke funny Spanish, like their grandparents.

"As in proper Spanish?" I asked.

"Yeah like Spain Spanish or something, you don't sound Mexican."

I don't sound Mexican.

For years, I had tried to lose what isolated me and now that I had, I was told that I didn't sound Mexican while speaking Spanish. This would be even more pronounced when I began taking Spanish classes. I realized that I knew more Spanish than my classmates. I never thought less of them. I knew that they were the products of living with two cultures and had their own separate identity. It just bothered me that they proudly claimed that they were Mexican when they couldn't speak well in Spanish. And it was these people, who I thought I would have the most in common with, who isolated me and said I was trying to be white. Trying to be white? During a group activity in my mathematics course, I was partnered with one of these individuals. Having completed our work early we began to discuss non-academic topics and we ended up laughing together.

"You know for a white boy you really aren't that bad Alberto" said my partner.

"Could you please explain to me why I am a white boy? Last I checked you and I were of the same pigment."

"Well it's not just how you talk but how you dress, like you come in like a teacher with your shirt tucked in and wearing a belt and all. If you knew anything about real Mexicans you would know that's not how we dress. You try to copy to the white kids too hard. That's why people look at you funny."

If classmates like him had dared to travel to Mexico City dressed in their pajama pants and oversized t-shirts they would be ridiculed and called out for indecency. The idea that only the wealthy and Anglo could be taken seriously and respected in higher circles infuriated me and drove me mad. Frustrated beyond belief about being called an impostor, I began telling everyone that asked that my family had come to the United States as a means of escaping the civil war in Spain. It would not be until my senior year of high school that I would be introduced to other individuals who had the same upbringing and were tasked with the same challenges. They understood where I was coming from and why I lied to try and separate myself.

It was most apparent just how isolated I was when I was asked to be a part of the top one hundred breakfast at my school. I was one of the only Hispanics there and I didn't know whether that was a bad thing or if I should be proud or if I should be ashamed of myself for even noticing. The only other individual there who I knew had Latin parents was a good friend of mine whose parents were from Puerto Rico. He looked "American" because of his fair skin, and his eyes were light brown, hazel some would say. While enjoying the Oreo muffins --the most American pastry I had ever heard of, second only to bacon donuts-- I asked my friend if it bothered him that we were the only Hispanics at the event. He replied in a manner that shocked me and made me question who he was.

"I stopped thinking that my parents were foreigners a long time ago." He said, "Since I don't speak Spanish I consider myself white, to be honest. I know that language doesn't define your race but since I don't 
even know how to say hi, I see myself as pure bred American."

Both of his parents had thick accents and proudly told everyone that they were from Puerto Rico. Hearing my friend speak this way made me see things differently.

The question of who I was began when my teacher did not understand that Balam was my real name and not something I made up. The two personalities that I had developed since then divided me every time I stepped outside the front door of my house. The consequences that would come with this dual identity would lead me to wonder if any part of me was Mexican. The question is, who am I? If someone was to ask me what I consider myself to be I could only provide one answer: I am American. I don't have the connections and ties I once did for the home country of my parents, and which was once my own.

I may never find a real home or be considered an American by others, but I only feel that I have one home. It is and will always be the United States. 